\title{
Are Physical Assaults by Wives and Girlfriends a Major Social Problem?
}

\author{
A Review of the Literature \\ DANIEL G. SAUNDERS \\ University of Michigan
}

\begin{abstract}
Research that shows approximately equal rates of dating and domestic violence by men and women has been used to challenge the priority given to services for abused women. This article reviews the scientific evidence for gender equality in rates of lethal and nonlethal intimate partner violence. Among the problems noted in studies showing gender equality are the ways in which questions about violence are framed, exclusion of items about sexual abuse and stalking, and exclusion of separated couples. Studies without these problems show much higher rates of violence by men. Furthermore, the physical and psychological consequences of victimization are consistently more severe for women.
\end{abstract}

Ever since the first survey results on domestic violence were published more than 20 years ago, a controversy has existed regarding the extent of violence by men and women. In the 1970s, Steinmetz's publications on the "battered husband syndrome," (e.g., Steinmetz, 1977-1978) were met with charges of the "battered data syndrome" (Pleck, Pleck, Grossman, \& Bart, 19771978). In the 1980s, some authors claimed that domestic violence was a "falsely framed issue," and the "truth" was that men were just as victimized as women (McNeely \& Robinson-Simpson, 1987). Others responded with a description of "other truths" about women's need to use violence defensively (e.g., Saunders, 1988). The controversy persists today despite the increasing rigor of research methods. Social scientists responsible for conducting

AUTHOR'S NOTE: The author is very grateful to the editors of this special issue, Sue Osthoff, Shamita Das Dasgupta, and Andrea Bible; to the anonymous reviewers for their help in revising the manuscript; and to Roxanne Webster and Terri Torkko for their help with it.

VIOLENCE AGAINST WOMEN, Vol. 8 No. 12, December 2002 1424-1448

DOI: $10.1177 / 107780102237964$

(c) 2002 Sage Publications

1424 
large-scale national studies remain on opposite sides of the debate (Straus, 1997, 1999; Tjaden \& Thoennes, 2000).

The implications of the controversy go far beyond the halls of academia. On one side of the controversy are some men's rights groups who use scholarly publications to further their belief that widespread bias exists against men and that such bias affects them negatively in child custody disputes. For example, the Men's Defense Association, assisting men with "divorce discrimination," has an aim: "to protect the traditional image of fathers, family and manhood from the onslaught of 'politically correct' thinking that men are evil, violent and unnecessary in child development" (Men's Defense Association, 2001). In a recent suit filed by some members of the National Coalition of Free Men and a father's rights group against the state of Minnesota, the complaint requested that funding for domestic violence programs be stopped on the grounds of discrimination against men. Specifically, they claimed that rates of violence against men approach, equal, or exceed those against women and further claim that programs are designed only for aiding women. These men's rights groups seem to rely heavily on an annotated bibliography that states there are "117 scholarly investigations, 94 empirical studies and 23 reviews and / or analyses, which demonstrate that women are as physically aggressive, or more aggressive, than men in their relationships with their spouses or male partners" (Fiebert, 1998, p. 1). They also rely on a review and commentary by Farrell (1999) who makes a similar claim. In these reviews, scholarly studies and reviews by others (e.g., Straus, 1997) are used uncritically, without stating the methodological limitations described in these studies and reviews. Consequently, although there appears to be a scientific consensus for evidence of widespread violence against husbands and boyfriends, a closer look at the evidence reveals that there is no such consensus.

How women's violence is framed can lead to disparate policy outcomes in other areas as well. For example, if domestic violence is framed by law enforcement personnel in a particular jurisdiction primarily as "mutual combat," there will probably be a higher number of dual arrests in that community. However, if much of women's violence is framed as self-defense or a reaction to years of abuse, laws and policies need to be developed that take into account the history and motives for violence. Without a full 
understanding of women's use of violence, some severe, negative outcomes can occur for them (Renzetti, 1999). For example, an increasing number of battered women have been arrested for allegedly assaulting their partners (Hooper, 1996; Miller, 2001). In some jurisdictions, as many as a fourth of arrests for domestic violence include women, either as the sole arrestee or in a "dual arrest" situation, and there is evidence of increasing rates of women's arrests following adoption of mandatory arrest policies (Dasgupta, 2001; Lincoln Family Violence Council, 2000; Miller, 2001; Saunders, 1995). The laws in some states reflect the need to determine the "primary aggressor" when both partners appear to have been violent. If defensive violence is not detected, victims face the double stigmas of criminal records (if convicted) and, in some jurisdictions, of being court-ordered to mandatory "batterer" treatment. Assault convictions can lead to lost custody battles, deportation of immigrants, restrictions from some jobs, and other adverse consequences (Dasgupta, 2001; Martin, 1997; National Clearinghouse for the Defense of Battered Women, 2001). Furthermore, once arrested, victims are likely to be reluctant to call the police again.

In this article, I review the scientific literature in an attempt to answer the question of whether assaults by wives and girlfriends constitute a major social problem. The literature on same-sex violence includes a similar controversy about mutual combat and defensive violence. However, same-sex violence is not discussed here because I am focusing on the unique challenges in understanding male-female violence and the practice implications of this understanding. Because of the possible social policy impact of the Fiebert publications $(1997,1998)$, these will be critiqued more extensively. The purpose here is not to determine if one gender is more capable of aggression than the other; there is fairly consistent evidence that women have the potential for aggression (e.g., Eagly \& Steffen, 1986). Rather, the questions I explore are whether the motives, contexts, and consequences of aggression against intimate partners differ for men and women, and if so, how do they differ? In general, do these differences make violence by one gender a major social problem? In particular, how much violence should be labeled as assaultive or abusive, and how much as justifiable aggression or violence meant to defend oneself or others? 
This review will show that women are much more victimized than men, and intervention and prevention efforts must continue to focus on woman abuse. I use the definitions of violence used in the studies reviewed, which typically define violence as physical aggression. However, it is also recognized that physical aggression is almost always accompanied by psychological abuse (O'Leary, 1999), which may have more lasting emotional effects than physical aggression. Gender differences in the concomitants of physical aggression reviewed here point to differing patterns of men's and women's behavior consistent with broad definitions of "battering" that include any behavior that denies one personal power and establishes control in the relationship (Dasgupta, 1999). The operationalization of such broad definitions is likely to show even greater gender disparities. However, studies conducted thus far rarely measure patterns of coercive control, and then usually with measures of psychological abuse asking only about the abuse of women with no comparison to men.

\section{GENERAL INADEQUACIES OF PRIOR RESEARCH}

Many studies, including the majority of studies in the Fiebert $(1997,1998)$ bibliographies, simply count the rates of violence by men and women. They fail to include three important variables: the motives of each partner, the rates of initiation of violence by each partner in the relationship and in particular episodes, and the physical and psychological consequences of the violence to each partner (Dobash, Dobash, Wilson, \& Daly, 1992). Murray Straus, a researcher frequently cited by those claiming that women's violence is a major social problem, makes the same point: "The number of assaults by itself . . . ignores the contexts, meanings, and consequences of these assaults" (Straus, 1997, p. 216).

Among the studies that analyze motive, initiation, and consequence, summarized below, women are generally shown to be more victimized than men. For example, reviews by Straus (1993, $1995,1997)$ describe many qualifications of prior research that preclude firm conclusions about the extent of men's victimization. Straus (1995) also concludes that women are the primary victims of partner abuse because they are "physically injured to the 
point of needing medical attention seven times as often as husbands, they suffer psychological injury at much higher rates, and they are locked into violent marriages because of the economic inequalities of American society" (p. 33). He concludes one review by stating that the "first priority in services for victims and in prevention and control must continue to be directed toward assaults by men" (Straus, 1997, p. 219).

\section{ALTERNATIVE EXPLANATIONS FOR GENDER EQUALITY IN RATES OF VIOLENCE}

Although many studies show approximately equal rates of violence by men and women in intimate relations, many other studies show much higher rates of violence by men. To give just three examples: (a) The National Crime Survey indicated that when victimization occurred, $95 \%$ of the victims were women, and $5 \%$ were men (U.S. Department of Justice, Bureau of Justice Statistics, 1980); (b) in a study of domestic disturbance calls to the police that involved injury, women were injured $94 \%$ of the time, compared with $14 \%$ of the men (Berk, Berk, Loseke \& Rauma, 1983); and (c) a random survey of the U.S. population showed that $22 \%$ of the women and $7 \%$ of the men experienced violence from an intimate partner over a lifetime (Tjaden \& Thoennes, 1998). As noted above, however, even these rates as reflections of assaults are misleading because they do not take into account the motives and initiation of the violence.

The different rates across studies have been attributed to different types of samples (Archer, 2000) and to the different contexts of the surveys as presented to respondents (family conflict versus crime) (Johnson, 1995; Nazroo, 1995; Straus, 1999). Some reviews of the literature point to sampling differences as the most likely explanation for gender differences in prevalence rates. Samples that are community based and often representative appear to differ from help-seeking samples or samples from the criminal justice system that are likely to include the most serious cases (Archer, 2000; Johnson, 1995). Studies with shelter samples, for example, include physical aggression by women but much higher rates by men; community samples, on the other hand, tend to show about equal rates of aggression (Archer, 2000). Gender differences in reports to the police or other agencies have been 
attributed to men's embarrassment at being victimized, but there is some evidence that they are actually more likely to report victimization than women (Gelles, 1979; Schwartz, 1987).

In addition to sample type, rates also seem to differ based on the context of the survey. Surveys placed in the context of criminal behavior show less frequent and more severe violence in general and higher prevalence rates for men (Nazroo, 1995; Straus, 1999). Surveys of family conflict show approximately equal rates by gender, which could be related to the context of spats and conflicts in which questions about violence are placed. For example, the introduction to the widely used Conflict Tactics Scales (CTS) (Straus, 1990b) reads:

No matter how well a couple gets along, there are times when they disagree, get annoyed with the other person, or just have spats or fights because they're in a bad mood or tired or for some other reason. They also use many different ways of trying to settle their differences. I'm going to read some things that you and your (spouse/ partner) might do when you have an argument. I would like you to tell me how many times... in the past 12 months you ... (p. 33)

Respondents might assume that only aggression arising from conflict should be reported (DeKeseredy \& Schwartz, 1998). These are probably less serious incidents than those arising from control tactics and a desire to dominate. The developer of the widely used CTS concludes that studies of family conflict, which usually use these scales, include very few severe cases and thus "may provide an erroneous basis for policies and interventions" (Straus, 1999, p. 29). The normalization of conflict-based fights given in the introduction and asking how often a behavior occurred rather than whether it occurred could also lead to overreporting of violence that is equal across gender (Tjaden \& Thoennes, 2000). The critiques of the CTS are very important to consider, given that almost all of the studies in major reviews (e.g., Archer, 2000; Fiebert, 1998) use the scales or very similar scales. A possible effect of the sampling differences and screening biases noted above is that two distinct types of violence are being uncovered, what one team of researchers calls "intimate terrorism" and "common couple violence" (Johnson \& Ferraro, 2000).

Another problem with most studies is that they neglect to include sexual abuse. Rates of sexual abuse of women by an 
intimate partner were more than 5 times higher than rates of sexual abuse of men by an intimate partner in a large-scale study of college students (Makepeace, 1986), from 2 to 60 times higher in high-school samples (Molidor \& Tolman, 1998; O'Keefe \& Treister, 1998), and 20 times higher in a random survey of the U.S. population (Tjaden \& Thoennes, 2000). Thus, inclusion of sexual abuse is likely to show clear gender differences. In response to criticism that the CTS did not include sexual coercion items, they were recently added to its latest version (CTS-2) (Straus, Hamby, Boney-McCoy, \& Sugarman, 1996).

The family conflict studies by Straus and Gelles (1990) leave out another major form of violence, that which occurs among separated and divorced couples. A higher percentage of women than men are physically abused, harassed, and stalked after the relationship ends. In a random U.S. survey, $4 \%$ of the women and $0.5 \%$ of the men reported being stalked by a current or past partner (Tjaden \& Thoennes, 2001). In a random survey of the Canadian population, $24 \%$ said that violence became worse after separation, 37\% said it stayed the same, and 39\% said it occurred for the first time (Statistics Canada, 2001). Women in this study were significantly more likely to be severely victimized: $60 \%$ of women and $25 \%$ of men required medical attention. The results of the National Crime Victimization Survey show that violence against separated women is more than 8 times higher than rates for married women (Bachman \& Saltzman, 1995).

\section{EVIDENCE FOR HIGHER RATES OF DOMESTIC HOMICIDE OF WOMEN}

Of all partner homicides in the past few years, about $70 \%$ of the victims were women killed by male partners, and 30\% were men killed by female partners (see Saunders \& Browne, 2000, for a review). Before the mid-1980s, the number of women victims of intimate homicide was not much higher than that of male victims; however, by the 1990s, about three women were killed for every man killed. The major reason for this increasing gender gap is a substantial decline in the rates of husbands and ex-husbands being killed by wives. A decrease in homicides of wives and ex- 
wives has occurred, but the decline is not as substantial (Browne, Williams, \& Dutton, 1999; Dugan, Nagin, \& Rosenfeld, 1999; Greenfeld et al., 1998). The rate of girlfriends and ex-girlfriends killed by their male partners remained about the same over the past 20 years (Greenfeld et al., 1998). Reviews that do not include homicides after 1985 are likely to be misleading regarding gender differences.

\section{GENDER DIFFERENCES IN MOTIVES FOR LETHAL VIOLENCE}

Studies of domestic homicide show clearly that women are much more likely to use violence in self-defense than are men (see Saunders \& Browne, 2000, for a review). The importance of selfdefense in partner homicides by women was noted as far back as Wolfgang's 1958 study of criminal homicides. In his analysis of police and court records, he found that at least $60 \%$ of husbands killed by their wives had "precipitated" their own deaths, which meant they were the first to use physical force, strike blows, or threaten with a weapon. Only 9\% of wife victims struck first or made threats (Wolfgang, 1967). These figures were based on "provocation recognized by the courts," and do not necessarily reflect the number of wives who had actually experienced physical abuse or threat from their partners.

Homicides by women generally occur as part of an attempt to stop their partner from harming them or a child any further, to prevent an attack they believe to be imminent and life-threatening, or during a violent assault (Browne, 1986, 1987; Dugan et al., 1999; Grant, 1995; Jurik \& Winn, 1990; Maguigan, 1991). In one study, women who killed male partners reported a much higher level of fear than men who killed female partners (Stout \& Brown, 1995). Mann $(1988,1992)$ also found that women often reported a selfdefense motive (32\% to $57 \%$ in two cities), but she interpreted these reports as "excuses" by the women. However, based on evidence of prior assaults, threats, and physical injuries, judges and juries often believe that such homicides are in self-defense or that they involve strong mitigating circumstances (Langan \& Dawson, 1995). The research by Mann, cited above, is used in some reviews 
(McNeely \& Robinson-Simpson, 1987; Straus, 1993, 1997), to try to show that women do not kill in self-defense. However, Mann's interpretation is open to question because she does not provide evidence for doubting the women's credibility. Other studies that question claims of self-defense are based on extremely small samples (Jurik \& Gregware, 1989).

In contrast to women's motives, empirical and clinical studies indicate that men's motives for killing their female partners appear to revolve more around jealousy and a need to control, especially during the imminent or actual termination of a relationship (Barnard, Vera, Vera, \& Newman, 1982; Block, 2000; Block \& Christakos, 1995; Cazenave \& Zahn, 1992; Goetting, 1995; Stout, 1993; Wilson, Daly, \& Daniele, 1995). Self-defense is estimated to be 7 to 10 times less frequent for husbands than for wives (Campbell, 1981; Wolfgang, 1958). There is growing evidence that separation or the threat of separation is a significant precipitant of partner homicides by men (Campbell, 1981; Wilson \& Daly, 1992, 1993). These homicides are followed by suicide in about a third of the cases (Saunders \& Browne, 2000). Wilson and Daly (1992) contend that men who kill usually feel entitled to control the lives of their wives or girlfriends. They summarize the findings on male/ female differences in homicide motivations this way:

Men often hunt down and kill a spouse who has left them; women hardly ever behave similarly. Men kill wives as part of planned murder-suicides; analogous acts by women are almost unheard of. Men kill in response to revelations of wifely infidelity; women almost never respond similarly, although their mates are more often adulterous. Men often kill wives after subjecting them to lengthy periods of coercive abuse and assaults; the roles in such cases are seldom if ever reversed. Men perpetrate familicidal massacres, killing spouse and children together; women do not. Moreover, its seems clear that a large proportion of the spousal killings perpetrated by wives, but almost none of those perpetrated by husbands, are acts of self-defense. Unlike men, women kill male partners after years of suffering physical violence, after they have exhausted all available sources of assistance, when they feel trapped, and because they fear for their own lives. (p. 206)

A more recent review of research supports these gender differences in motives for using violence (Archer, 2000). 


\section{GENDER DIFFERENCES IN MOTIVES FOR NON-LETHAL VIOLENCE}

For non-lethal violence, the research on motivation is less clear. Studies on motives for violence include samples of college students (DeKeseredy, Saunders, Schwartz, \& Alvi, 1997; Makepeace, 1986), battered women (Barnett, Lee, \& Thelen, 1997; Gondolf, 1998; Saunders, 1986), clients at marital clinics (Cascardi \& Vivian, 1995), and men and women arrested for domestic violence (Dasgupta, 1999; Hamberger, Lohr, Bonge, \& Tolin, 1997). These studies indicate that much of the violence used by female victims is in self-defense. Because information about a respondent's motives must rely on self-report, respondents' credibility can be questioned. In one study of battered women, social desirability response bias, or the tendency to fake answers in an attempt to appear good, was not related to their reports of selfdefense (Saunders, 1986). In this study, the majority of the battered women reported using violence in self-defense. In a study of women whose partners were ordered into treatment for abuse, the majority reported using violence, with two thirds saying it was in self-defense and another $22 \%$ saying it was out of fear for themselves (Gondolf, 1998). In a study of college students, women were twice as likely as men to report self-defense as a motive, and men were 3 times as likely as women to report intimidation as a motive (Makepeace, 1986). Other studies of students also show significantly higher rates of defensive violence by women than men (Follingstad, Wright, Lloyd, \& Sebastian, 1991; Foshee, 1996; Gagne \& Lavoie, 1993). Even in samples of those arrested for domestic violence, women give self-protection as the most common motive (Dasgupta, 1999), and women are more likely than men to be assessed in counseling programs as acting in self-defense (Hamberger, 1997; Hamberger et al., 1997). In a study of 39 arrested women, only 3 were assessed at treatment intake as the primary aggressor (Hamberger \& Arnold, 1990). The term assault is normally defined as an unlawful attack with the connotation of culpable action. It is very misleading to apply it to justifiable, defensive violence, yet many publications (e.g., Fiebert, 1997, 1998; Steinmetz, 1977-1978; Straus, 1993) refer to assaults by women when self-defense has not been ruled out as a motive. 
Motives other than self-defense described by battered women include: retaliation for previous violence (Carrado, George, Loxam, Jones, \& Templar, 1996; Hamberger, 1997; Hamberger et al., 1997), getting the partner's attention or otherwise trying to "get through" to the partner (Carrado et al., 1996; Dasgupta, 1999), trying to engage emotionally (Fiebert \& Gonzalez, 1997), and showing anger and retaliating for emotional hurt (Dasgupta, 1999; Follingstad et al., 1991). Violence by women is often related to a lack of social support (Barnett, Martinez, \& Keyson, 1996) and lack of perceived or real options, sometimes termed "learned helplessness" (Wilson, Vercella, Brems, Benning, \& Refro, 1992).

Women of color in particular may be left on their own to fend off attacks. For example, African American women in one study were less likely than European American women to call the police, go to court, or enter a shelter, and they are more likely to fight back or injure their partners while defending themselves (Joseph, 1997). Other studies focus on the backgrounds and traits of women who use violence, such as their childhood victimization and substance abuse, but these findings go beyond the scope of this review. Given the reality that violence often escalates when women use violence against a partner (e.g., Bachman \& Carmody, 1994), helping them to find alternative ways to meet their needs will be important for violence prevention.

In contrast to women's motives, men's motives for using nonlethal violence against their female partners often include the intent to intimidate (Makepeace, 1986), "show who is boss" (Barnett et al., 1997), coerce her to do something (Cascardi \& Vivian, 1995; Hamberger et al., 1997), and punish unwanted behavior (Hamberger et al., 1997). Expression of anger is a motive common to both men and women (Cascardi \& Vivian, 1995; Makepeace, 1986).

Some studies of motives are flawed because they use questionnaire items that are ambiguous or do not ask about self-defense motives. One study of women's motives for using violence (Fiebert \& Gonzalez, 1997) failed to ask about self-defense. Another study asking about motives (Carrado et al., 1996) included a question about using violence that clearly addressed the motive of self-defense. This study included other questions that could be interpreted as defensive violence. However, the answers to these questions were not counted as self-defense, and 
thus defensive violence was likely to be underreported. Actions that sound like retaliation (angrily trying to hurt the other) or fighting back may be defensive and legally justifiable, especially when the victim is smaller than the attacker (Schneider \& Jordan, 1978). In one study of battered women, items on fighting back against violence and defensive violence ("protecting oneself from immediate harm") were highly correlated with each other (Saunders, 1986).

\section{INITIATION OF VIOLENCE}

Many of the studies contending that women initiate violence as often or more often than men have methodological problems, which include: speculative conclusions, using ambiguous questions, reporting only minor forms of violence, and using the terms mutual combat or reciprocal violence when all that is known is that both partners have been violent at some point in the past. For example, one of the researchers at the heart of the original debate about whether or not women are as violent as men (Steinmetz, 1977-1978) did not measure initiation of violence or motives for violence as she claimed. The detailed critiques of Steinmetz's work published in the professional literature (Field \& Kirchner, 1978; Gelles, 1979; Pagelow, 1984; Pleck et al., 1977-1978; Saunders, 1988) are often overlooked. Other studies claiming to establish reciprocal violence used a single ambiguous item that may reflect minor violence: "hit or throw things" (Bland \& Orn, 1986; Sorenson \& Telles, 1991).

One of the most widely cited studies for support of gender equality of the prevalence and initiation rates of domestic violence is the 1985 National Family Violence Survey (Straus \& Gelles, 1990). However, there are several problems with its questions on the initiation of violence. Stets and Straus (1990) point out some of the problems, specifically that women may have answered the question in terms of who started the argument rather than who actually initiated the violence and that the history of abuse over the entire relationship is unknown. Straus (1997) further points out that initiation of violence can still be in response to perceived great harm when there is a long history of abuse. Another limitation is that the question was phrased in a way that assumes mutual combat ("Let's talk about the last time you and 
your partner got into a physical fight ... "), and such "common couple violence" is less likely to reflect severe violence that is perpetrated only by the man (Johnson, 2001).

The 1975 National Family Violence Survey (Straus, Gelles, \& Steinmetz, 1981) provides some information on violence initiation. In an analysis of 10 behaviors during the worst episode, both men and women reported that men used violence first in $60 \%$ of the episodes (Saunders, 1989). Men were more likely to engage in multiple acts of violence in the same episode: $70 \%$ of the men compared with $30 \%$ of the women. Men also accounted for almost three fourths of the total number of multiple, aggressive actions (73\% of the total number of actions).

In a small-scale study, when 52 women arrested for domestic violence were asked about initiation of the overall pattern of violence in the relationship, 51\% said the man started the pattern, and $27 \%$ said the woman started it (Hamberger, 1997). When analyzing individual episodes, the women reported that the men initiated violence more often. In a study of high-school students, $70 \%$ of the girls reported their partners initiated the violence, whereas $27 \%$ of the boys reported initiation by a partner. Boys were more likely to see the initiation as mutual (Molidor \& Tolman, 1998).

\section{CONSEQUENCES OF THE VIOLENCE}

Both physical and psychological consequences of domestic violence are generally greater for women than men. The 1985 National Family Violence Survey asked respondents if they had been "hurt badly enough as a result of a conflict between you to need to see a doctor" (Stets \& Straus, 1990). Three percent of the women victims and $0.4 \%$ of the men victims reported that they had such an injury. Of those who said they experienced aggression from the "severe" category, $7.3 \%$ of the women and $1 \%$ of the men said they were hurt badly enough to need to see a doctor. Women in the severe injury category tended to be more likely than men to report taking more time off from work and spending more days in bed due to illness. The rates of injuries and their outcomes probably would have been higher if several specific questions had been asked about the types of injuries. The question used also might have been understood by some to mean that help was 
sought. Some studies show that, out of shame or fear, $20 \%$ or more of battered women do not seek medical help even when they need it (Dobash \& Dobash, 1979; Walker, 1984). Straus (1997) recognizes the need to adjust violence rates for injury when he states: "The injury adjusted rate for assaults by men is six times greater than the rate of domestic assaults by women" (p. 211). Other nationally representative surveys in North America show similar results (Brush, 1990; Morse, 1995; Statistics Canada, 2001; Tjaden \& Thoennes, 2001). For example, the National Violence Against Women Survey found a $42 \%$ injury rate for women versus $19 \%$ for men for the most recent incident of violence; $11 \%$ of the women and $4 \%$ of the men received medical care; and $18 \%$ of the women and $11 \%$ of the men lost time from work (Tjaden \& Thoennes, 2001).

Such findings also exist for nonrepresentative student samples. For example, Molidor and Tolman (1998) reported that highschool girls were 2 to 4 times more likely than boys to report they were "hurt a lot," had bruises, and needed medical attention in response to the worst incident; boys were more likely to laugh in response to violence (54\% vs. 10\%). Makepeace (1986) found that college women had 2 to 3 times the injury rate as men. Cascardi, Langhinrichsen and Vivian (1992) and Cascardi and Vivian (1995) showed that in marital clinic samples, wives had higher rates of injuries than husbands. Other studies also show higher rates of injuries to women and girls (Cantos, Neidig, \& O'Leary, 1994; Foshee, 1996; Langhinrichsen-Rohling, Neidig, \& Thorn, 1995; Straus et al., 1996). A recent review article came to the same conclusion: Men inflict more frequent and more severe injuries than women (Archer, 2000). Gender differences in injuries are most striking in police studies (Bell, 1985; Berk et al., 1983; Dobash \& Dobash, 1979; Kenny, 1981; McLeod, 1984; Saunders, 1980; Vanfossen, 1979), which are likely to include only the most severe assaults (Kaufman Kantor \& Straus, 1990). The above information on injury rates does not give a complete picture because injuries, even severe injuries, can be the result of defensive violence. To be able to counter men's strength and size, women usually need a knife or gun to defend themselves (e.g., Chimbos, 1978), and therefore severe injury can result.

Researchers have studied other consequences of violence as well. The 1985 National Family Violence Survey reported that the 
proportion of severely victimized women with high levels of psychosomatic symptoms, stress, and depression was nearly double the proportion of men with such symptoms who received similar types of violence (Stets \& Straus, 1990). Another representative survey showed higher levels of anxiety among women (Magdol et al., 1997). A national study in Canada reported that $40 \%$ of female victims and $11 \%$ of male victims feared for their lives at the time of separation (Statistics Canada, 2001). In the National Violence Against Women Survey, $45 \%$ of the women and $20 \%$ of the men who were assaulted "feared bodily injury or death" during the most recent assault (Tjaden \& Thoennes, 2000). Nonrepresentative studies also show higher levels of psychological trauma in women than in men, including higher levels of depression (Cascardi et al, 1992; Vivian \& Langhinrichsen-Rohling, 1994), anxiety or fear (Jacobsen et al., 1994; Langhinrichsen-Rohling et al., 1995; Matthews, 1984), and post-traumatic stress symptoms (Callahan, Tolman, \& Saunders, in press). One study of men and women filing assault complaints found only two differences among many measures: Women had more pain and less "vitality" (e.g., were more tired); however, the study included only 10 men (McFarlane, Willson, Malecha, \& Lemmey, 2000).

\section{OTHER PROBLEMS WITH STUDIES REVIEWED}

There are several other problems, detailed below, with the studies covered in the reviews by Fiebert $(1997,1998)$ and others (Farrell, 1999).

1. Most of the representative community and national studies may underreport the most severe forms of abuse, which are likely to require criminal justice and social service interventions. Nonresponse rates are as high as $40 \%$, and offenders and victims in severe cases may be the most reluctant to respond to surveys or be the most difficult to locate (Johnson, 1995). Straus (1997) notes that community samples contain very few cases involving severe assaults that occur every week or more often and that "men tend to be the predominant aggressors in this type of case, but representative sample studies cannot reveal that, because they include few if any such cases" and "community surveys can tell us little about what to do about these extreme cases because the samples contain too few to analyze separately" (p. 216). 
2. Many studies present results by severity level (e.g., Arias, Samios, \& O'Leary, 1987; Magdol et al., 1997; Morse, 1995; Stets \& Henderson, 1991). However, the CTS does not have any scientifically validated subscales of minor and severe violence (Straus, 1990a). The acts of violence on this and similar scales have not been adjusted for size and strength differences between men and women. A push by a man can do severe damage; hitting by a woman may do little damage (DeKeseredy \& Schwartz, 1998; Saunders, 1989). When reports and reviews refer to severe assaults by women, therefore, they may imply falsely that violence by women is a major social problem.

3. Five of the citations in the Fiebert (1998) review were based on the National Family Violence Surveys (Straus, 1980; Straus, 1995; Straus \& Gelles, 1986; Straus, Gelles, \& Steinmetz, 1981; Straus, \& Kaufman Kantor, 1994), and the same samples are used more than once, thus creating an inflated sense of gender equality in rates of violence. Only one of these citations (Straus, 1995), covering the 1975 and 1985 surveys, is needed to describe the rates of violence by gender.

4. Some of the publications listed in the Fiebert bibliography do not add to our knowledge of gender differences in violence. One study asked about the level of sympathy to victims when the perpetrator was a husband or wife (Feather, 1996); another study pertained to the acceptance of research findings about "female assaultive behavior" (Fiebert, 1996). One study used comic strips from 1950 as evidence of wives' greater aggression (Saenger, 1963). Some are studies of predictors of violence but do not compare violence levels by gender (e.g., Mihalic \& Elliot, 1997). Some of the publications are commentaries (e.g., Farrell, 1999; Gelles, 1994), which do not include new scientific evidence and do not attempt to present balanced conclusions.

\section{WOMEN'S GREATER NEED FOR RESOURCES}

In addition to the need to adjust rates of violence for motives, initiation, and consequences of intimate partner violence, female victims generally require more resources because they tend to be more entrapped in violent relationships. Material resources are closely related to the ability to leave a violent relationship. In one review I conducted (Saunders, 1988), eight of nine studies showed that employed women and women with higher socioeconomic status were more likely to leave a violent relationship. More recent reviews draw the same conclusion (Barnett \& LaViolette, 1993; Holtzworth-Munroe, Smutzler, \& Sandin, 1997; Rhodes \& 
McKenzie, 1998). As described above, women are also more likely than men to be abused, stalked, and killed after leaving a partner, thus they often have realistic fears of serious harm should they try to leave.

Straus (1976) and other researchers have recognized that institutionalized sexism helps to keep battered women in violent relationships by creating differences in material resources for men and women. Although the economic status of women has improved in the past 25 years, a considerable gender gap continues to exist. When women divorce, a substantial proportion of them have their income cut in half, whereas men's useable incomes stay the same or increase on average (Bartfield, 2000; Garrison, 1994; Skilken \& McKenny, 1996).

\section{RESOURCES FOR BATTERED WOMEN AS HOMICIDE PREVENTION FOR MEN}

Because services for battered women are being attacked by some as discriminatory against men, it seems worth pointing out that men may be the largest beneficiaries of these services. The decline in partner homicide rates of men by their women partners over the past 20 years shows some correlation with the establishment of protections for women faced with violent and assaultive partners (Saunders \& Browne, 2000). For example, Browne and Williams (1989) analyzed national homicide data for the years of 1976 through 1984 and noted a decline of more than 25\% in the rates of women killing male partners during that time period; those states having more domestic violence laws and other resources (e.g., shelters, crisis lines, support groups) for battered women had lower rates of partner homicides by all women. Two other studies found similar results (Dugan et al., 1999; Stout, 1989). Therefore, a decrease in legal aid and social services to domestic violence victims, most of whom are women, would be likely to lead to increased homicides of men by women who are defending their lives. 


\section{SUMMARY AND CONCLUSION}

In conclusion, there is no consensus in the scientific community that violence against men by their intimate female partners constitutes a major social problem. However, there is a strong scientific consensus that violence against women by their intimate partners constitutes a major social problem. The claim that women initiate and carry out assaults against their partners as often as men is inaccurate because it is based on speculation or inadequate research, as described in this review. Moreover, many studies that were excluded from previously published reviews (e.g., Fiebert, 1997, 1998) show much higher rates of violence directed at female partners than male partners. These are usually police and crime studies that involve the most injurious cases. Many studies that show equal rates of violence by female and male partners fail to account for important factors such as the use of defensive violence and the traumatic consequences of violence. Women tend to use violence in self-defense more than men, especially for the most severe types of violence. The term assault is applied mistakenly to these cases in many publications. Many studies also exclude sexual assault and stalking, which are experienced at much higher rates by women.

Because women are more psychologically and physically injured than men by violence inflicted by their partners, women generally require more resources and services to cope with the violence. They also tend to require more resources and services to leave violent relationships than male victims. Even after leaving a violent relationship, women are at greater risk than men of being stalked and killed. Therefore, current policies and services directed primarily at women survivors of domestic violence are warranted. Legal remedies such as arrest and restraining orders are gender neutral, and domestic violence programs offer services to both men and women. However, the conclusions of this review support legislative action, such as the Violence Against Women Act, that in some instances emphasizes violence perpetrated against women. Specific practices are also supported-for example, policies and training procedures that guide police officers in recognizing the signs of defensive violence. 
Although the variables of violent interactions reviewed above, particularly initiation, motives, and consequences, showed that women are more victimized than men in intimate relationships, research is needed that combines all of these dimensions in the same study. Future studies do not have to discard the CTS measure of violence or other measures like it. Rather, these measures need to be modified to take gender differences into account. The development of a gender-weighted measure of domestic violence stands as a major research need. Studies also need to include sexual violence, samples of separated couples, and injury severity that is unrelated to help seeking. To ignore these research variables is to ignore the enormous implications that research results have for social policies and interventions aimed at ending domestic violence.

\section{REFERENCES}

Archer, J. (2000). Sex differences in aggression between heterosexual partners: A metaanalytic review. Psychological Bulletin, 126, 651-680.

Arias, I., Samios, M., \& O'Leary, K. D. (1987). Prevalence and correlates of physical aggression during courtship. Journal of Interpersonal Violence, 2, 82-90.

Bachman, R., \& Carmody, D. C. (1994). Fighting fire with fire: The effects of victim resistance in intimate versus stranger perpetrated assaults against females. Journal of Family Violence, 9, 317-332.

Bachman, R., \& Saltzman, L. (1995). Violence against women: Estimates from the redesigned National Crime Victimization Survey. Washington, DC: U.S. Department of Justice, Bureau of Justice Statistics.

Barnard, G. W., Vera, H., Vera, M. I., \& Newman, G. (1982). 'Til death do us part: A study of spouse murder. Bulletin of the American Academy of Psychiatry and the Law, 10, 271-280.

Barnett, O. W., \& LaViolette, A. D. (1993). It could happen to anyone: Why battered women stay. Newbury Park, CA: Sage.

Barnett, O. W., Lee, C. Y., \& Thelen, R. E. (1997). Gender differences in attributions of selfdefense and control in interpartner aggression. Violence Against Women, 3, 462-481.

Barnett, O. W., Martinez, T. E., \& Keyson, M. (1996). The relationship between violence, social support, and self-blame in battered women. Journal of Interpersonal Violence, 11, 221-233.

Bartfield, J. (2000). Child support and the postdivorce economic well-being of mothers, fathers, and children. Demography, 37, 203-213.

Bell, D. J. (1985, November). Domestic violence victimization: A multiyear perspective. Paper presented at the annual meeting of the American Society of Criminology, San Diego, CA.

Berk, R. A., Berk, S., Loseke, D. R., \& Rauma, D. (1983). Mutual combat and other family violence myths. In D. Finkelhor, R. Gelles, G. Hotaling, \& M. Straus (Eds.), The dark side of families (pp. 197-212). Beverly Hills, CA: Sage.

Bland, R., \& Orn, H. (1986). Family violence and psychiatric disorder. Canadian Journal of Psychiatry, 31, 129-137. 
Block, C. (2000). The Chicago Women's Health Risk Study risk of serious injury or death in intimate violence: A collaborative research project. Chicago, IL: Illinois Criminal Justice Information Authority.

Block, C. R., \& Christakos, A. (1995). Intimate partner homicide in Chicago over 29 years. Crime and Delinquency, 41, 496-526.

Browne, A. (1986). Assault and homicide at home: When battered women kill. In M. J. Saks \& L. Saxe (Eds.), Advances in applied social psychology (pp. 57-79). Hillsdale, NJ: Erlbaum.

Browne, A. (1987). When battered women kill. New York: Free Press.

Browne, A., \& Williams, K. R. (1989). Exploring the effect of resource availability and the likelihood of female-perpetrated homicides. Law \& Society Review, 23, 75-94.

Browne, A., Williams, K. R., \& Dutton, D. G. (1999). Homicide between intimate partners: A 20-year review. In M. D. Smith \& M. A. Zahn (Eds.), Homicide: A sourcebook of social research (pp. 55-78). Thousand Oaks, CA: Sage.

Brush, L. D. (1990). Violent acts and injurious outcomes in married couples: Methodological issues in the National Survey of Families and Households. Gender E Society, 4, 56-67.

Callahan, M. R., Tolman, R. M., \& Saunders, D. G. (in press). Adolescent dating violence victimization and psychological well-being. Journal of Adolescent Research.

Campbell, J. C. (1981). Misogyny and homicide of women. Advances in Nursing Science/ Women's Health, 3, 67-85.

Cantos, A. L., Neidig, P., \& O'Leary, K. D. (1994). Injuries of women and men in a treatment program for domestic violence. Journal of Family Violence, 9, 113-124.

Carrado, M., George, M. J., Loxam, E., Jones, L., \& Templar, D. (1996). Aggression in British heterosexual relationships: A descriptive analysis. Aggressive Behavior, 22, 401-415.

Cascardi, M., Langhinrichsen, J., \& Vivian, D. (1992). Marital aggression: Impact, injury, and health correlates for husbands and wives. Archives of Internal Medicine, 152, 11781184.

Cascardi, M., \& Vivian, D. (1995). Context for specific episodes of marital violence: Gender and severity of violence differences. Journal of Family Violence, 10, 265-293.

Cazenave, N. A., \& Zahn, M. A. (1992). Women, murder, and male domination: Police reports of domestic homicide in Chicago and Philadelphia. In E. C. Viano (Ed.), Intimate violence: Interdisciplinary perspectives (pp. 83-96). Washington, DC: Hemisphere Publishing.

Chimbos, P. D. (1978). Marital violence: A study of interspousal homicide. San Francisco: R \& E Associates.

Dasgupta, S. D. (1999). Just like men? A critical view of violence by women. In M. F. Shepard \& E. L. Pence (Eds.), Coordinating community responses to domestic violence: Lessons from Duluth and beyond (pp. 195-222). Thousand Oaks, CA: Sage.

Dasgupta, S. D. (2001). Towards an understanding of women's use of non-lethal violence in intimate heterosexual relationships. Retrieved October 6, 2001, from http:// www.vawnet.org/VNL/library/general/AR_womviol.html

DeKeseredy, W. S., Saunders, D. G., Schwartz, M. D., \& Alvi, S. (1997). The meanings and motives for women's use of violence in Canadian college dating relationships: Results from a national survey. Sociological Spectrum, 17, 199-222.

DeKeseredy, W. S., \& Schwartz, M. D. (1998). Measuring the extent of woman abuse in intimate heterosexual relationships: A critique of the Conflict Tactics Scales. Retrieved June 4, 2002, from http://www.vawnet.org/VNL/library/general/AR_ctscrit.html

Dobash, R. P., \& Dobash, R. C. (1979). Violence against wives. New York: Free Press.

Dobash, R. P., Dobash, R. E., Wilson, M., \& Daly, M. (1992). The myth of sexual symmetry in marital violence. Social Problems, 39, 71-91.

Dugan, L., Nagin, D., \& Rosenfeld, R. (1999). Explaining the decline in intimate partner homicide: The effects of changing domesticity, women's status, and domestic violence resources. Homicide Studies, 3, 187-214. 
Eagly, A. H., \& Steffen, V. J. (1986). Gender and aggressive behavior: A meta-analytic review of the social psychological literature. Psychological Bulletin, 100, 309-330.

Farrell, W. (1999). Women can't hear what men don't say. New York: Tarcher/Putnam

Feather, N. T. (1996). Domestic violence, gender and perceptions of justice. Sex Roles, 35, 507-519.

Fiebert, M. S. (1996). College students' perception of men as victims of women's assaultive behavior. Perceptual \& Motor Skills, 82, 49-50.

Fiebert, M. S. (1997). References examining assaults by women on their spouses or male partners: An annotated bibliography. Sexuality and Culture, 1, 273-286.

Fiebert, M. S. (1998). References examining assaults by women on their spouses or male partners: An annotated bibliography. Retrieved March 4, 2001, from http://www.vix.com/ menmag/fiebert.htm

Fiebert, M. S., \& Gonzalez, D. M. (1997). Women who initiate assaults: The reasons offered for such behavior. Psychological Reports, 80, 583-590.

Field, M. D., \& Kirchner, R. M. (1978). Battered women are still in need: A reply to Steinmetz. Victimology, 3, 216-222.

Follingstad, D. R., Wright, S., Lloyd S., \& Sebastian, J. A. (1991). Sex differences in motivations and effects in dating violence. Family Relations, 40, 51-57.

Foshee, V. A. (1996). Gender differences in adolescent dating abuse prevalence, types and injuries. Health Education Research, 11, 275-286.

Gagne, M., \& Lavoie, F. (1993). Young people's views on the causes of violence in adolescents' romantic relationships. Canada's Mental Health, 41, 11-15.

Garrison, M. (1994). The economic consequences of divorce. Family and Conciliation Courts Review, 32, 10-26.

Gelles, R. J. (1979). The truth about abused husbands. In R. J. Gelles (Ed.), Family violence (pp. 137-144). Beverly Hills, CA: Sage.

Gelles, R. J. (1994). Research and advocacy: Can one wear two hats? Family Process, 33, 9395.

Goetting, A. (1995). Homicide in families and other special populations. New York: Springer.

Gondolf, E. W. (1998). The victims of court-ordered batterers: Their victimization, helpseeking, and perceptions. Violence Against Women, 4, 659-676.

Grant, C. A. (1995). Women who kill: The impact of abuse. Issues in Mental Health Nursing, $16,315-326$.

Greenfeld, L. A., Rand, M. R., Craven, D., Klaus, P. A., Perkins, C. A., Ringel, C., et al. (1998). Violence by intimates: Analysis of data on crimes by current or former spouses, boyfriends, and girlfriends. Washington, DC: U.S. Department of Justice, Bureau of Justice Statistics.

Hamberger, L. K. (1997). Female offenders in domestic violence: A look at actions in their context. Journal of Aggression, Maltreatment \& Trauma, 1, 117-129.

Hamberger, L. K., \& Arnold, J. (1990). The impact of mandatory arrest on domestic violence perpetrator counseling services. Family Violence Bulletin, 6, 10-12.

Hamberger, L. K., Lohr, J. M., Bonge, D., \& Tolin, D. F. (1997). An empirical classification of motivations for domestic violence. Violence Against Women, 3, 401-423.

Holtzworth-Munroe, A., Smutzler, N., \& Sandin, E. (1997). A brief review of the research on husband violence: Part II: The psychological effects of husband violence on battered women and their children. Aggression and Violent Behavior, 2, 179-213.

Hooper, M. (1996). When domestic violence diversion is no longer an option: What to do with the female offender. Berkeley Women's Law Journal, 11, 168-181.

Jacobsen, N. S., Gottman, J. M., Waltz, J., Rushe, R., Bacock, J., \& Holtzworth-Munroe, A. (1994). Affect, verbal content, and psychophysiology in the arguments of couples with a violent husband. Journal of Consulting and Criminal Psychology, 62, 982-988.

Johnson, M. P. (1995). Patriarchal terrorism and common couple violence: Two forms of violence against women. Journal of Marriage and the Family, 57, 283-294. 
Johnson, M. P. (2001). Conflict and control: Symmetry and asymmetry in domestic violence. In A. Booth, A. C. Crouter, \& M. Clements (Eds.), Couples in conflict (pp. 95-104). Mahwah, NJ: Lawrence Erlbaum.

Johnson, M. P., \& Ferraro, K. (2000). Research on domestic violence in the 1990s: Making distinctions. Journal of Marriage and the Family, 62, 948-963.

Joseph, J. (1997). Woman battering: A comparative analysis of Black and White women. In G. Kaufman Kantor \& J. Jasinski (Eds.), Out of the darkness: Contemporary perspectives on family violence (pp. 161-169). Thousand Oaks, CA: Sage.

Jurik, N. C., \& Gregware, P. (1989). A method for murder: An interactionist analysis of homicides by women. Unpublished manuscript, Arizona State University, Tempe, AZ.

Jurik, N. C., \& Winn, R. (1990). Gender and homicide: A comparison of men and women who kill. Violence and Victims, 5, 227-242.

Kaufman Kantor, G., \& Straus, M. A. (1990). Response of victims and the police to assaults on wives. In M. A. Straus \& R. J. Gelles (Eds.), Physical violence in American families (pp. 473-488). New Brunswick, NJ: Transaction.

Kenny, M. A. (1981). Family relationships in domestic violence disturbances. Dissertation Abstracts International, 41 (8-A). (UMI No. 3734-A)

Langan, P. A., \& Dawson, J. M. (1995). Spouse murder defendants in large urban counties. Washington, DC: U.S. Department of Justice, Bureau of Justice Statistics.

Langhinrichsen-Rohling, J., Neidig, P., \& Thorn, G. (1995). Violent marriages: Gender differences in levels of current violence and past abuse. Journal of Family Violence, 10, 159176.

Lincoln Family Violence Council. (2000). Report on domestic violence for 2000. Lincoln, NE: Family Violence Council, Lincoln Medical Education Foundation.

Magdol, L., Moffit, T. E., Caspi, A., Fagan, J., Newman, D. L., \& Silva, P. J. (1997). Gender differences in partner violence in a birth cohort of 21-year-olds: Bridging the gap between clinical and epidemiological approaches. Journal of Consulting and Clinical Psychology, 65, 68-78.

Maguigan, H. (1991). Battered women and self-defense: Myths and misconceptions in current reform proposals. University of Pennsylvania Law Review, 140, 379-486.

Makepeace, J. M. (1986). Gender differences in courtship violence victimization. Family Relations, 35, 383-388.

Mann, C. R. (1988). Getting even?: Women who kill in domestic encounters. In S. L. Johann \& F. Osanka (Eds.), Representing battered women who kill (pp. 8-26). Springfield, IL: Charles C. Thomas.

Mann, C. R. (1992). Female murderers and their motives: A tale of two cities. In E. Viano (Ed.), Intimate violence: Interdisciplinary perspectives (pp. 73-81). New York: Hemisphere.

Martin, M. E. (1997). Double your trouble: Dual arrest in family violence. Journal of Family Violence, 12, 139-157.

Matthews, W. J. (1984). Violence in college couples. College Student Journal, 18, 150-158.

McFarlane, J., Willson, P., Malecha, A., \& Lemmey, D. (2000). Intimate partner violence: A gender comparison. Journal of Interpersonal Violence, 15, 158-169.

McLeod, M. (1984). Women against men: An examination of domestic violence based on an analysis of official data and national victimization data. Justice Quarterly, 1, 171-193.

McNeely, R. L., \& Robinson-Simpson, G. (1987). The truth about domestic violence: A falsely framed issue. Social Work, 32, 485-490.

Men's Defense Association. (2001). Mission statement. Retrieved April 11, 2001, from http:/ / www.mensdefense.org/

Mihalic, S. W., \& Elliot, D. (1997). A social learning theory model of marital violence. Journal of Family Violence, 12, 21-47.

Miller, S. L. (2001). The paradox of women arrested for domestic violence: Criminal justice professionals and service providers respond. Violence Against Women, 7, 1339-1376. 
Molidor, C., \& Tolman, R. M. (1998). Gender and contextual factors in adolescent dating violence. Violence Against Women, 4, 180-194.

Morse, B. J. (1995). Beyond the Conflict Tactics Scale: Assessing gender differences in partner violence. Violence and Victims, 10, 251-272.

National Clearinghouse for the Defense of Battered Women. (2001, February). The impact of arrests and convictions on battered women. Unpublished document. Philadelphia, PA: National Clearinghouse for the Defense of Battered Women.

Nazroo, J. (1995). Uncovering gender differences in the use of marital violence: The effect of methodology. Sociology, 29, 475-495.

O'Keefe, M., \& Treister. L. (1998). Victims of dating violence among high school students: Are the predictors different for males and females? Violence Against Women, 4, 195-223.

O'Leary, K. D. (1999). Psychological abuse: A variable deserving critical attention in domestic violence. Violence and Victims, 14, 1-14.

Pagelow, M. D. (1984). The 'battered husband syndrome': Social problem or much ado about little? Sociological Review Monograph, 31, 173-195.

Pleck, E., Pleck, J. H., Grossman, M., \& Bart, P. B. (1977-1978). The battered data syndrome: A comment on Steinmetz's article. Victimology: An International Journal, 2, 680-683.

Renzetti, C. (1999). The challenge to feminism posed by women's use of violence in intimate relationships. In S. Lamb (Ed.), New versions of victims: Feminists struggle with the concept (pp. 42-56). New York: New York University Press.

Rhodes, N. R., \& McKenzie, E. B. (1998). Why do battered women stay? Three decades of research. Aggression and Violent Behavior, 3, 391-406.

Saenger, G. (1963). Male and female relations in the American comic strip. In D. M. White \& R. H. Abel (Eds.), The funnies, an American idiom (pp. 219-231). Glencoe, NY: The Free Press.

Saunders, D. G. (1980). The police response to battered women: Predictors of officers' use of arrest, counseling, and minimal action. (Doctoral dissertation, University of WisconsinMadison, 1979). Dissertation Abstracts International, Publication No. 80-08840.

Saunders, D. G. (1986). When battered women use violence: Husband abuse or selfdefense? Violence and Victims, 1, 47-60.

Saunders, D. G. (1988). Other "truths" about domestic violence: A reply to McNeely and Robinson-Simpson. Social Work, 33, 179-183.

Saunders, D. G. (1989, November). Who hits first and who hurts most? Evidence for the greater victimization of women in intimate relationships. Paper presented at the annual meeting of the American Society of Criminology, Reno, Nevada.

Saunders, D. G. (1995). The tendency to arrest victims of domestic violence: A preliminary analysis of officer characteristics. Journal of Interpersonal Violence, 10, 147-158.

Saunders, D. G., \& Browne, A. (2000). Intimate partner homicide. In R. T. Ammerman \& M. Hersen (Eds.), Case studies in family violence (2nd ed., pp. 415-449). New York: Plenum.

Schneider, E. M., \& Jordan, S. B. (1978). Representation of women who defend themselves in response to physical or sexual assault. Family Law Review, 1, 118-132.

Schwartz, M. (1987). Gender and injury in spousal assault. Sociological Focus, 20, 61-75.

Skilken, C. B., \& McKenny, P. C. (1996). Implications of feminist scholarship for the study of women's postdivorce economic disadvantage. Family Relations, 45, 91-97.

Sorenson, S. B., \& Telles, C. A. (1991). Self reports of spousal violence in a Mexican-American and non-Hispanic White population. Violence and Victims, 6, 3-15.

Statistics Canada. (2001). Family violence in Canada: A statistical profile. Ottawa, Canada: National Clearinghouse on Family Violence.

Steinmetz, S. K. (1977-1978). The battered husband syndrome. Victimology: An International Journal, 2, 499-509.

Stets, J. E., \& Henderson, D. A. (1991). Contextual factors surrounding conflict resolution while dating: Results from a national study. Family Relations, 40, 29-40. 
Stets, J. E., \& Straus, M. A. (1990). Gender differences in reporting marital violence and its medical and psychological consequences. In M. A. Straus \& R. J. Gelles (Eds.), Physical violence in American families: Risk factors and adaptations to violence in 8,145 families (pp. 151-166). New Brunswick, NJ: Transaction.

Stout, K. D. (1989). Intimate femicide: Effects of legislation and social services. Affilia, 4, 2127.

Stout, K. D. (1993). Intimate femicide: A study of men who have killed their mates. Journal of Offender Rehabilitation, 19, 81-94.

Stout, K. D., \& Brown, P. (1995). Legal and social differences between men and women who kill intimate partners. Affilia, 10, 194-205.

Straus, M. A. (1976). Sexual inequality, cultural norms, and wife-beating. Victimology: An International Journal, 1, 54-76.

Straus, M. A. (1980). Victims and aggressors in marital violence. American Behavioral Scientist, 23, 681-704.

Straus, M. A. (1990a). The Conflict Tactics Scales and its critics: An evaluation and new data on validity and reliability. In M. A. Straus \& R.J. Gelles (Eds.), Physical violence in American Families (pp. 49-74). New Brunswick, NJ: Transaction.

Straus, M. A. (1990b). Measuring intrafamily conflict and violence: The Conflict Tactics (CT) Scales. In M. A. Straus \& R.J. Gelles (Eds.), Physical violence in American Families (pp. 29-48). New Brunswick, NJ: Transaction.

Straus, M. A. (1993). Physical assaults by wives: A major social problem. In R. J. Gelles \& D. R. Loseke (Eds.), Current controversies on family violence (pp. 67-87). Newbury Park, CA: Sage.

Straus, M. A. (1995). Trends in cultural norms and rates of partner violence: An update to 1992. In S. M. Stich \& M. A. Straus (Eds.), Understanding partner violence: Prevalence, causes, consequences, and solutions (pp. 30-33). Minneapolis, MN: National Council on Family Relations.

Straus, M. A. (1997). Physical assaults by women partners: A major social problem. In M. R. Walsh (Ed.), Women, men and gender: Ongoing debates (pp. 210-221). New Haven: Yale University Press.

Straus, M. A. (1999). The controversy over domestic violence by women: A methodological, theoretical, and sociology of science analysis. In X. B. Arriaga \& S. Oskamp (Eds.), Violence in intimate relationships (pp. 17-44). Thousand Oaks, CA: Sage.

Straus, M.A. \& Gelles, R.J. (1986). Societal change and change in family violence from 1975 to 1985 as revealed by two national surveys. Journal of Marriage and the Family, 45, 465479.

Straus, M. A., \& Gelles, R. J. (Eds.) (1990). Physical violence in American families. New York: Transaction.

Straus, M. A., Gelles, R. J., \& Steinmetz, S. K. (1981). Behind closed doors: Violence in the American family. Garden City, NY: Anchor.

Straus, M. A., Hamby, S. L., Boney-McCoy, S., \& Sugarman, D. B. (1996). The Revised Conflict Tactics Scales (CTS2): Development and preliminary psychometric data. Journal of Family Issues, 17, 283-316.

Straus, M. A., \& Kaufman Kantor, G. (1994, July). Change in spouse abuse rates from 19751992: A comparison of three national surveys in the United States. Paper presented at the Thirteenth World Congress of Sociology, Bielefeld, Germany.

Tjaden, P., \& Thoennes, N. (1998). Prevalence, incidence, and consequences of violence against women: Findings from the National Violence Against Women Survey. Washington, DC: National Institute of Justice and Centers for Disease Control and Prevention.

Tjaden, P., \& Thoennes, N. (2000). Full report of the prevalence, incidence, and consequences of violence against women: Findings from the National Violence Against Women Survey . 
Washington, DC: National Institute of Justice and Centers for Disease Control and Prevention.

Tjaden, P., \& Thoennes, N. (2001). Prevalence and consequences of male-to-female and female-to-male intimate partner violence as measured by the National Violence Against Women Survey. Violence Against Women, 6, 142-161.

U.S. Department of Justice, Bureau of Justice Statistics. (1980). Intimate victims: A study of violence among friends and relatives. Washington, DC: Government Printing Office.

Vanfossen, B.E. (1979). Intersexual violence in Monroe County, New York. Victimology: An International Journal, 4, 299-304.

Vivian, D., \& Langhinrichsen-Rohling, J. (1994). Are bi-directionally violent couples mutually victimized? A gender-sensitive comparison. Violence and Victims, 9, 107-124.

Walker, L. E. (1984). The battered woman syndrome. New York: Springer.

Wilson, M. I., \& Daly, M. (1992). Who kills whom in spouse killings? On the exceptional sex ratio of spousal homicides in the United States. Criminology, 30, 189-215.

Wilson, M., \& Daly, M. (1993). Spousal homicide risk and estrangement. Violence and Victims, 8, 3-17.

Wilson, M., Daly, M., \& Daniele, A. (1995). Familicide: The killing of spouse and children. Aggressive Behavior, 21, 275-291.

Wilson, K., Vercella, R., Brems, C., Benning, D., \& Refro, D. (1992). Levels of learned helplessness in abused women. Women \& Therapy, 13, 53-67.

Wolfgang, M. E. (1958). Patterns in criminal homicide. New York: Wiley.

Wolfgang, M. E. (1967). A sociological analysis of criminal homicide. In M. E. Wolfgang (Ed.), Studies in homicide (pp. 15-28). New York: Harper \& Row.

Daniel G. Saunders, Ph.D., M.S.S.W., is associate professor at the University of Michigan, School of Social Work, where he teaches courses on social work practice, research, and domestic violence. He is codirector of the university's Interdisciplinary Research Program on Violence Across the Lifespan. He has consulted for the Department of Defense, the National Council of Juvenile and Family Court Judges, the National Institute of Justice, and the National Institute of Mental Health. His research focuses on offender program evaluation, the traumatic effects of victimization, and the responses of professionals and the public to dating and domestic violence. 